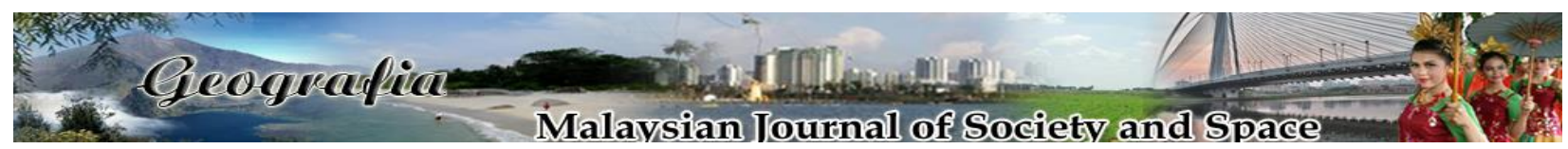

\title{
The probability factor influences the level of financial well-being of workers in Malaysia
}

\author{
Zaimah, R. \\ Development of Science, Centre for Development, Social and Environmental, \\ Faculty of Social Sciences and Humanities, Universiti Kebangsaan Malaysia \\ Correspondence: Zaimah, R. (email: zaimahr@ukm.edu.my)
}

Received: 10 May 2019; Accepted: 19 July 2019; Published: 22 August 2019

\begin{abstract}
Generally, the dual-income family households earn higher income than the single-income family households as both husband and wife are working and earning money for the family. Dualincome households should have more advantages in terms of better level of financial well-being in comparison to single-income households. The workers in dual-income family are also expected to have a better level of financial well-being. Therefore, this study aims to determine the probability factors affecting the workers' level of financial well-being. The sample of the study was married workers in the public sector, with focus on workers who are in a dual-income family. The analysis unit in this study is the individual. A total of 415 married workers were analyzed in this study. Multinomial logistic regression analysis was applied in identifying the probability factors of various levels of financial well-being (low, moderate, high) which includes socioeconomic background, financial knowledge, financial behavior and financial decision making factors. The logistic regression analysis showed the socioeconomic background (age, monthly income, home ownership and financial product ownership), financial behavior and financial decision making of the husband have a significant relationship with the respondents' various levels of financial well-being. Factors such as age, monthly income, home ownership, financial product ownership and financial behavior were found to have an impact on financial well-being. Financial education needs to be implemented in the workplace to encourage workers to have good financial practices. This is necessary in order to ensure the financial well-being of their workers.
\end{abstract}

Keywords: behavior, decision making, dual-income families, financial well-being, knowledge, married workers 


\section{Introduction}

Issues concerning the workers' financial well-being have been largely addressed by many researchers internationally. However, in Malaysia it is an issue which has yet to be researched in depth (Nurul et al., 2005; Husniyah et al., 2005; Husniyah \& M. Fazilah, 2009; Zuroni \& Lin, 2012; Faoziah et al., 2013; Hasni, 2014; Diana-Rose \& Zariyawati, 2015; Nur Aisyatul et al., 2015; Nuraini \& Sabri, 2016; Poh \& Sabri, 2017; Mokhtar \& Husniyah, 2017). Most issues affecting the financial well-being of workers are due to the higher level of living costs, the burden of loan, lack of financial knowledge and weaknesses in financial management. Those factors have negatively impacted the daily living structures which have resulted in decreased level of productivity, deterioration of family relationship and personal health (Kim \& Garman, 2004; Xiao et al., 2004; Haron et al., 2010; Mokhtar \& Husniyah, 2017), as well as putting pressure on the workers.

In Malaysia, the mass media have reported many cases of failures in managing personal wealth effectively. It involves various variables such as the misuse of credit cards, extensive loans taken from loan sharks, suicidal cases and divorce cases which have either directly or indirectly resulted from financial problems. The numbers of individuals who have gone bankrupt have also increased from year to year (Bank Negara Malaysia, 2010). Moreover, it has been reported by the Malaysian Insolvency Department (2010), that a total of 1,086 public servants have been declared bankrupt in the year 2009. Between 2013 and 2017, a total of 100,610 Malaysians were declared bankrupt, of which 60\% were between 18 and 44 years old (Bank Negara Malaysia, 2013; 2018).

The increase in the number of dual-income families in Malaysia has taken place when women have started working (Economic Planning Unit, 2006; Zaimah et al., 2013). Accordingly, it is expected that there will be an increase in the financial well-being of a family comprising of working husband and wife working. Hence, it is necessary to conduct a study on the financial well-being of the workers in this dual-income family. In addition, this study is also in line with the national aspirations to ensure that every family is able to achieve a good quality of life and earn high income (Economic Planning Unit, 2010).

Theoretically, the dual-income families whereby both husband and wife are working should be able to improve their financial well-being rather than single-income family (Goldsmith, 2005). However, the real situation is not that easy. This is due to the rising cost of living, lifestyle changes, and consumption patterns among Malaysians (Economic Planning Unit, 2006). Therefore, a detailed study to determine the probability factors affecting their financial wellbeing is required (Toh \& Rusmawati, 2018; Noorhaslinda et al., 2018). More than that, this is because the financial well-being of an employee in the public sector is related to work productivity (Joo \& Garman, 1998; Kim \& Graman, 2004; Kim et al., 2004; Mokhtar \& Husniyah, 2017) and is a leading contributor to a higher employment rates in the country. Therefore, the objective of this paper is to determine the probability factors affecting the workers' level of financial well-being.

\section{Literature review}

Financial well-being refers to the subjective perception and the objective indicators of individual personal financial status (Cox et al., 2009). In short, the concept refers to the financial well-being 
of individual satisfaction of his/her financial situation (Porter \& Garman, 1993; Joo \& Garman, 1998; Kim et al., 2003; Goldsmith, 2005). For example, Porter and Garman (1993) defined financial well-being as a measure of individual financial circumstances based upon the objective and perception of financial position. While, Goldsmith (2005) referred to financial well-being as the adequacy and economic soundness of individual or family that includes efforts to protect themselves from economic risks such as loss of employment, sickness and poverty.

Financial well-being is greatly influenced by demographic criteria and personal financial behavior (O'Neill et al., 2005; Cox et al., 2009; Zuroni \& Lin, 2012). Individuals with lower financial well-being are usually young in age, have health problems, do not have their own home and have low income (O'Neill et al., 2005; Poh \& Sabri, 2017). They are also often faced with financial stress and have difficulty paying utility bills. On the other hand, individuals who have good financial well-being are older, own a home, are married, have no health problems and have high income. Thus the financial well-being of an individual should be measured objectively and subjectively (Baek \& DeVenay, 2004), because every individual who is in a similar financial situation, do not necessarily have the same perception of their financial well-being (Kim et al., 2003; Baek \& DeVenay, 2004).

The financial well-being of an individual or family is also related and influenced by many other factors such as financial knowledge, financial behavior, financial decisions and socioeconomic. Those with high levels of financial knowledge, usually also have high levels of financial well-being (Joo \& Grable, 2004; Baek \& DeVaney, 2004; Mokhtar \& Husniyah, 2017). Similarly, those who practise good financial behavior, also have high levels of financial wellbeing.

Socioeconomic factors such as gender, age, household size, marital status, number of children, level of education, occupation, income and number of income earner in the family (single or dual-income) (Cox et al., 2009; Shim et al., 2009; Rutherford \& Fox, 2010; Siswati \& Puspitawati, 2017; Mokhtar \& Husniyah, 2017) are also found to affect the financial well-being of an individual. In addition, factors such as low amount of credit card loan, positive perspectives on retirement, good family relationship (Xiao et al., 2004; Nur Aisyatul et al. 2015), good level of saving (Lown \& Ju, 2003; Hasni, 2014), have a variety of financial products (Worthington, 2004) and low amount of personal loan (Nuraini \& Sabri, 2016) have either directly or indirectly affected the individual financial well-being.

\section{Methods}

The data used in this study were taken from the 2008 Financial Well-Being Among Dual-Income Workers in Malaysia. A multi-stage sampling approach was used. First of all, six ministries were randomly selected from 28 ministries in the Federal Public Administration Office of Malaysia. Secondly, a list of married workers was gathered from the Human Resources Management Division of each ministry selected. A total number of 1,298 married workers with spouses who also worked were selected from the list. Out of these, 415 responded, reflecting a response rate of 32 percent. The unit of analysis is the individual which is either the husband or the wife. Data were gathered from the questionnaires answered by the respondents. The questionnaires were distributed using the leave and collect method. Data analysis was done descriptively and through inferences. Scales such as frequency, percentage, average and standard deviation were used to describe the socioeconomic background of the respondents. Meanwhile, logistic regression 
analysis was used to identify the probability factors that influence the level of financial wellbeing.

\section{Empirical model}

The dependent variables which were self-reported level of financial well-being were categorized into a scale of "low", "moderate" and "high". Since the response variable was comprised of multiple categories, multinomial logistic regression was used to estimate the effect of the independent variable on the log odds of reporting a high, moderate or low level. The logistic regression model used was specified as:

$$
\log [\mathrm{P} / 1-\mathrm{P}]=\beta 0+\beta 0+\beta 1 \mathrm{~K}+\beta 2 \mathrm{~B}+\beta 3 \mathrm{D}+\beta 4 \mathrm{G}+\mathrm{e}
$$

$\mathrm{P}$ referred to the probability that the respondents have reported moderate or low level of financial well-being (high level of financial well-being was the reference category). K represented the financial knowledge, $\mathrm{B}$ represented the financial behavior, D represented the financial decision making, and $\mathrm{G}$ represented a set of demographic variables that included gender, age, number of children, education level, job category, monthly income, home ownership, number of financial products, and financial contribution to the family.

\section{Variable measurement}

The dependent variable in this study is the financial well-being of married workers in the public sector from dual-income family. The measurement of financial well-being was done using the Malaysian Financial Well-Being Scale (MFWBS) developed by Jariah (2007) and adapted from In Charge Financial Distress/Financial Well-Being (IFDFW) by Prawitz et al. (2006). The scale measures 12 items on a scale of 1 to 10 where, $1=$ very low financial well-being to $10=$ very high financial well-being. The mean score of financial well-being was gathered using the score of 12 items divided into 12. Financial well-being was categorized into 3 levels; mean score of 1.0-4.0 (low), mean score of 5.0-6.0 (moderate), and mean score of 7.0-10.0 (high).

Financial knowledge was measured according to the answer score of 'true' on 10 statements related to personal financial knowledge. The correct answer was given a score of ' 1 ' and the total score on the financial knowledge of each respondent ranged from 1 to 8. Financial behavior was measured using a 5-Likert scale; $1=$ never to 5=always on the 10 statements related to monthly financial behavior. The total score of the respondents' financial behavior ranged from 15 to 50 . Financial decision making was determined based on the total score of husbands' financial decisions and total score of wives' financial decisions on 10 statements that involved financial decisions in the family.

The demographic variables in this study were gender, age, number of children, education level, job category, monthly income, home ownership, number of financial products, and financial contribution to the family. Gender was coded " 1 " if male, " 0 " otherwise. Age, number of children, monthly income, number of financial product and financial contribution to the family were continuous data. Education level was coded " 1 " if graduated, "0" otherwise, and job category was coded " 1 " if professional, " 0 " otherwise. 


\section{Results and discussion}

\section{Sample characteristics}

The socio-demographic characteristic of the sample are shown in Table 1. Among the 415 respondents, 47 percent were male and 53 percent were female. The average age of the respondents was 38 years old. The average years of marriage among the respondents were 11 years. The average number of children and household were 2 and 4 persons. Meanwhile, the average of duration of work was 13 years. The majority of respondents were non-university graduates $(59.8 \%)$ and only 40.2 percent were university graduates. In terms of service grade, only 38.3 percent of the respondents were at Grade 41-54 (professional staff) while most of the respondents (61.7\%) were at Grade 1-40 (support staff). The average monthly income of the respondents was RM3,579.00. The evarage monthly expenses of the respondents in this study was RM2,372.00. Among the respondents, nearly 55 percent had home ownership.

Table 1. Sociodemographic background

\begin{tabular}{lcc}
\hline & Frequency (\%) & Mean (SD) \\
\hline Gender: & $195(47.0)$ & - \\
- Men & $220(53.0)$ & - \\
- Women & - & $38(9.45)$ \\
Age & - & $11(9.18)$ \\
Duration of marriage & - & $2(1.77)$ \\
Number of children & - & $4(1.91)$ \\
Number of households & - & $13(10.20)$ \\
Duration of work & & - \\
Education level: & $166(40.2)$ & - \\
- University graduates & $249(59.8)$ & - \\
- Non-graduate & & - \\
Job category: & $159(38.3)$ & \\
- Professional & $256(61.7)$ & - \\
- Support & - & $2372(1575.37)$ \\
Monthly income (RM) & - & - \\
Monthly expenses (RM) & $228(54.9)$ & \\
Home ownership &
\end{tabular}

Figure 1 shows the financial products owned by the respondents. It was reported that emergency saving accounted for 84.3 percent of the product, retirement saving accounted for 60.2 percent, investment saving accounted for 74.5 percent, life insurance accounted for 59.5 percent, health insurance accounted for 55.4 percent and excluding accidental insurance accounted for 47.2 percent. Meanwhile, Figure 2 shows that the husband contributed more to the family income $(64.1 \%)$ as compared to the wife. Only a low percentage $(11.0 \%)$ of the respondents had equal sharing of income between husband and wife. The portion from the wife only amounted up to 24.8 percent. If a comparison is made between male respondents and female respondents, the three categories of income contribution will show the same patterns whereby the husband contributed more income than the wife even though both of them were working. 


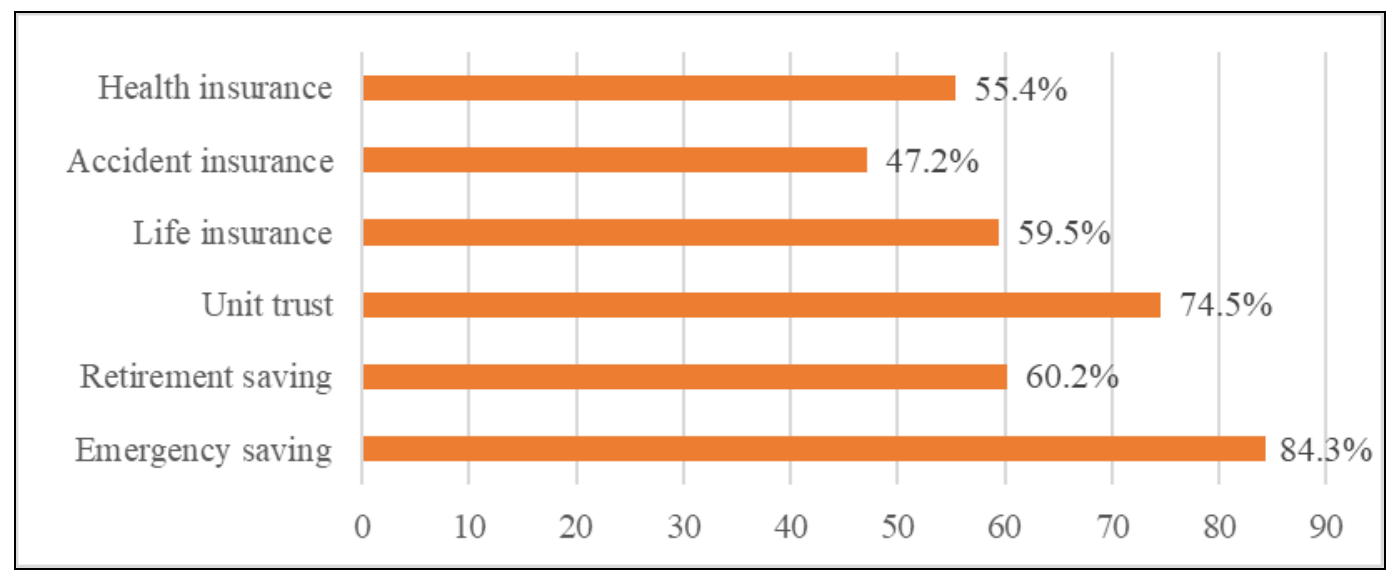

Figure 1. Financial product

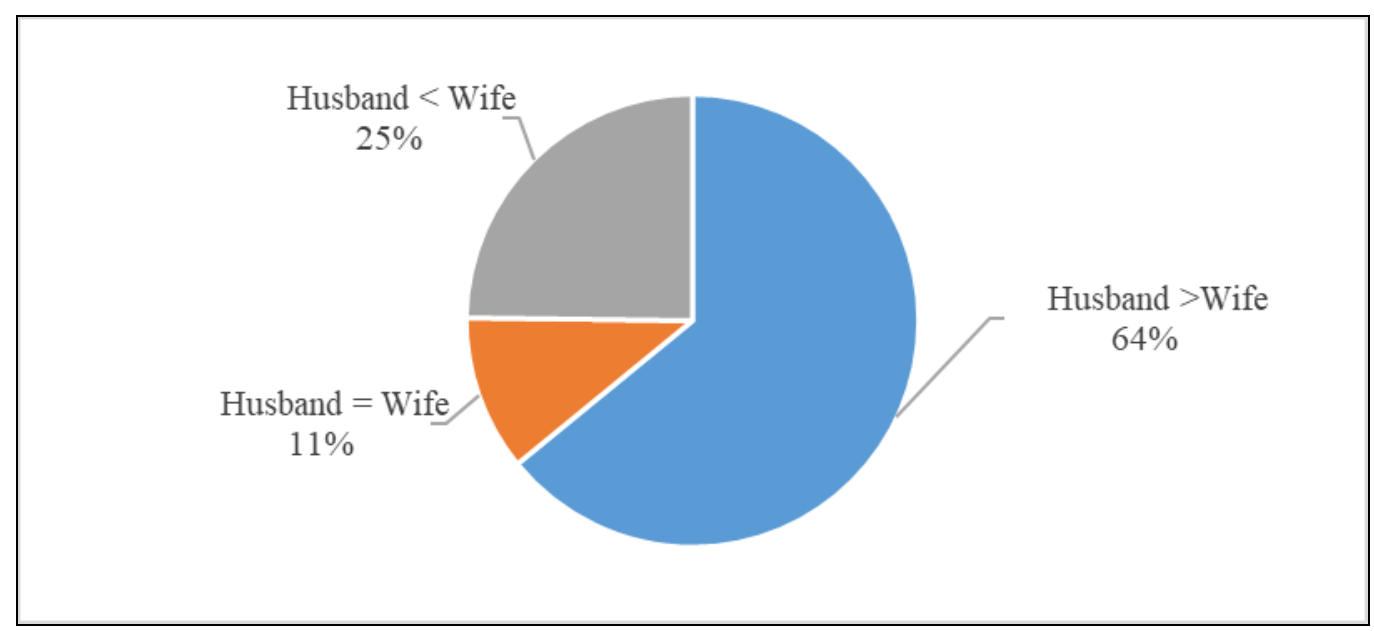

Figure 2. Income contribution

Factors influencing level of financial well-being

Table 2 shows the result of a multinomial logistic regression analysis. Research showed there was a significant relationship $(\chi 2=187.658, \mathrm{p}<.05)$ between socioeconomic background factor $(\mathrm{G})$, financial knowledge (K), financial behavior (B) and financial decision making (D) of the various financial well-being levels of dual-income workers among the public servants. The research model estimated that 43 percent of changes in the financial well-being (Pseudo R2 Nagelkerke $=0.427$ ) were described by the factors examined in the research. The classification precision rate was 67 percent better in comparison to the value of coincidence rate which was only 51.8 percent. The classification precision criteria were satisfactory and did not have multicollinearity between variables being studied. Research finding showed six variables: age, monthly income, home ownership, financial product ownership, financial behavior and the husband's decision making which contributed to the probability of having low levels of financial well-being as compared to high levels of financial well-being among dual-income family of public servants. 
Table 2. Result of multinomial logistic regression on financial well-being

\begin{tabular}{|c|c|c|c|c|c|c|}
\hline \multirow[t]{2}{*}{ Independent variables } & \multicolumn{3}{|c|}{ Low level } & \multicolumn{3}{|c|}{ Moderate level } \\
\hline & Beta & Sig. & $\operatorname{Exp}(B)$ & Beta & Sig. & $\operatorname{Exp}(B)$ \\
\hline Intercept & 18.331 & & & 9.057 & & \\
\hline \multicolumn{7}{|l|}{ A. Socioeconomic background: } \\
\hline $\begin{array}{l}\text { Gender: } \\
{[\text { men=1] }} \\
{[\text { women=2] }}\end{array}$ & $\begin{array}{c}-.349(.464) \\
0^{\mathrm{a}}\end{array}$ & .451 & .705 & $-.236(.266)$ & .736 & .790 \\
\hline Age & $-.146(.040)$ & .000 & .864 & $-.052(.019)$ & .008 & .950 \\
\hline Number of children & $.127(.171)$ & .458 & 1.135 & $.051(.094)$ & .584 & 1.053 \\
\hline \multicolumn{7}{|l|}{ Education level: } \\
\hline [Non graduate $=1]$ & $1.806(1.045)$ & .084 & 6.086 & $.385(.527)$ & .465 & 1.470 \\
\hline [University graduates $=2$ ] & $0^{\mathrm{a}}$ & & & & & \\
\hline $\begin{array}{l}\text { Job category: } \\
\text { [support }=1] \\
\text { [professional=2] }\end{array}$ & $\begin{array}{c}-1.605(1.017) \\
0^{\mathrm{a}}\end{array}$ & .144 & 0.201 & $-.284(.509)$ & .577 & .753 \\
\hline Monthly income & $.000(.000)$ & .632 & 1.000 & $.000(.000)$ & .042 & 1.000 \\
\hline \multicolumn{7}{|l|}{ Home ownership: } \\
\hline $\begin{array}{l}{[\mathrm{No}=1]} \\
{[\mathrm{Yes}=2]}\end{array}$ & $\begin{array}{c}-1.401(.564) \\
0^{\mathrm{a}}\end{array}$ & .013 & .246 & $-.299(.324)$ & .356 & .741 \\
\hline Ownership of financial product & $-1.069(.205)$ & .000 & .343 & $-.151(.128)$ & .237 & .860 \\
\hline Contribution to family income & $.000(.000)$ & .124 & 1.000 & $.000(.000)$ & .209 & 1.000 \\
\hline B. Financial knowledge & $.029(.185)$ & .875 & 1.030 & $-.066(.115)$ & .565 & .936 \\
\hline C. Financial behavior & $-.193(.039)$ & .000 & .824 & $-.125(.023)$ & .000 & .883 \\
\hline \multicolumn{7}{|l|}{ D. Financial decision making: } \\
\hline FDM by husband & $-.224(.107)$ & .037 & .800 & $-.027(.055)$ & .631 & .974 \\
\hline FDM by wife & $-.019(.110)$ & .863 & .981 & $.028(.054)$ & .607 & 1.028 \\
\hline
\end{tabular}

Note: Reference category is the high level of financial well-being

a Parameter " 0 " because of redundant

Figures in parentheses are errors

Psuedo $R^{2}=.427, \chi^{2}=187.658, \mathrm{df}=26, \mathrm{p}=.00$

a. Age

The result of the logistic regression test showed significant negative correlation $(\mathrm{p}=.000)$ between age with the probability of having a low as compared to a high level of financial wellbeing. This means that at every stage of aging, the rate of probability of having a low level of financial well-being would be reduced by 0.86 times. The result also showed significant negative correlation $(\mathrm{p}=.008)$ between the respondent's age with the probability of having a moderate level of financial well-being as compared to a high level of financial well-being. So, for each unit of increase in age, the probability rate of having moderate financial well-being would be reduced by 0.95 times. These two findings showed age did influence the level of financial well-being. Prior study had proven that age factor played a major role in influencing the financial well-being of respondents (Kim et al., 2003; Baek \& DeVaney, 2004; O’Neill, 2005; Diana-Rose \& Zirayawati, 2015; Nuraini \& Sabri, 2016). The finding clearly shows that as the respondents get older, they achieved better financial well-being. 


\section{b. Monthly income}

The result of the logistic regression test in Table 2 showed significant positive correlation $(\mathrm{p}=.042)$ between monthly income with the probability of having a moderate level of financial well-being rather than a high level of financial well-being. Meanwhile, for every increase in the monthly income, there was an increase in the probability (1.00 times) of having a moderate level of financial well-being. Prior research showed monthly income factor (either individual or family income) had direct relation with the financial well-being of the respondents (Kim et al., 2003; Baek \& DeVaney, 2004; Joo \& Grable, 2004; Nur Aisyatul et al., 2015; Nuraini \& Fazli, 2016; Poh \& Sabri, 2017).

\section{c. Home ownership}

Table 2 shows that each respondent who did not own a home had the probability ( 0.25 times) of having a low level of financial well-being rather than a high level of financial well-being. Chi square test $((\chi 2=10.679, \mathrm{df}=2, \mathrm{p}<.05)$ result showed significantly high correlation between financial well-being of respondents who owned a home with those who did not own a home. The research finding also clearly showed those who owned their homes relatively would have better chances in achieving a high level of financial well-being. The finding clearly supported the statement that says owning their own home would be one of the most important factors in influencing financial well-being (Joo \& Grable, 2004; Baek \& DeVaney, 2004).

\section{d. Ownership of financial product}

Owning a financial product could be a factor influencing the financial well-being of dual-income family in the public sector. There were significant negative correlation $(p=.000)$ between the number of financial products they owned with the probability of having a low level as compared to a high level of financial well-being. For each unit of financial product owned, the probability rate of having low levels of financial well-being would be reduced by 0.34 times. The result also showed owning more variety of financial products would give advantage to the security of having strong financial support. The finding was in line with the need of achieving success in personal financial security (Kapoor et al., 2004; Garman \& Forgue, 2006).

\section{e. Financial behavior}

The result of the logistic regression test in Table 2 showed negative significant correlation $(\mathrm{p}=$. 000) between the respondents' financial behavior with the probability of having a low level as compared to a high level of financial well-being. The increased score of financial behavior would reduce the probability of having low levels of financial well-being by 0.82 times. Finding also showed significant negative correlation $(\mathrm{p}=.000)$ between the probability of having a moderate level of financial well-being with the probability of having a high level of financial well-being. It means that the increment in the score of financial behavior would reduce the probability of having a moderate as compared to a high level of financial well-being by 0.88 times. The finding was similar to prior research (Kim et al., 2003; Joo \& Grable, 2004; Zuroni \& Lin, 2012; Nur Aisyatul et al., 2015) which stated that good financial behavior would influence the level of financial well-being. 


\section{f. The husband's financial decision}

The husband's financial decision making factor did influence the financial well-being of the dual-income family. The logistic regression analysis showed significant negative correlation $(p=.037)$ between the husband's financial decision making with the probability of having a low as compared to a high level of financial well-being (refer to Table 2). Each unit of increment in the score of the husband's decision making would reduce the probability of having low levels of financial well-being by 0.80 times. This situation was due to the higher contribution of income of the husband as compared to the wife. The Chi-square test $(\chi 2=11.101, \mathrm{df}=2, \mathrm{p}<.05)$ showed a significant difference between the levels of financial well-being with the income contribution of both husband and wife in the family. Finding also showed the percentage of the husband's contribution was more than the wife at each level of financial well-being; low level (60.0\%), moderate level $(60.8 \%)$, and high level $(64.1 \%)$. The finding was similar with prior research $(\chi 2=11.101, \mathrm{df}=2, \mathrm{p}<.05)$ that stated the financial decision making would influence the distribution of wealth or financial resources in the household.

\section{Discussion}

The logistic regression results on workers who are married in the dual-income families show that age factor influenced the probability of variation of their financial well-being. The workers financial well-being will increase if he is older and if he has a high income. Older workers have a higher level of financial well-being than the younger workers in the dual-income families in the public sector. The workers profile in a dual-income family shows that those in the high-level financial well-being have an average age of 41 years. At the initial working stage (young age), the workers have income but not much can be saved because they spend a lot on meeting the needs of family life. However, when they reached middle age and are approaching retirement, the saving rate should be high and this condition leads to a relatively higher level of financial well-being. Prior study had proven that age factor played a major role in influencing the financial well-being of respondents (Kim et al., 2003; Baek \& DeVaney, 2004; O’Neill, 2005; Diana-Rose \& Zirayawati, 2015; Nuraini \& Sabri, 2016). In summary, the finding clearly stated that as the respondents get older, they achieved better financial well-being.

The monthly income of the workers who are married in a dual-income family also influenced the probability variation of their financial well-being levels. The high-income workers have high levels of financial well-being as compared to the low-dual-income families of the workers. The profiles of the workers who are married in a dual-income family show that those in the high-level financial well-being category have an average monthly income of RM4,596,00. Prior research showed monthly income factor (either individual or family income) had direct relation with the financial well-being of the respondents (Kim et al., 2003; Baek \& DeVaney, 2004; Joo \& Grable, 2004; Nur Aisyatul et al., 2015; Nuraini \& Fazli, 2016; Poh \& Sabri, 2017). However, it is not necessarily 'true' in a situation where the workers with high income levels since they were young. In such situation, practice and inculcating positive financial behaviors, such as planning, controlling, saving, protecting and investing need to be done throughout life so that financial well-being can be achieved and maintained.

Factors of home ownership also influenced the well-being of the married workers in a dualincome family. Home ownership reduces the likelihood of the workers in a dual-income family on low-level financial well-being relatively to the high level of financial well-being. The finding 
clearly supported the statement that says owning their own home would be one of the most important factors in influencing financial well-being (Joo \& Grable, 2004; Baek \& DeVaney, 2004). Home ownership and having various ownership of financial products are factors which significantly reduce the risk of being in a low-level and middle-level financial well-being compared to high-level financial well-being among the workers who are married in a dualincome family. Individuals will feel safer if they have their own home compared to being able to pay rent.

Ownership of various financial products also reduces the likelihood of the workers in a dualincome family to be at a low level of financial well-being compared to the high level of financial well-being. By owning more variety of financial products would give advantage to the security of having strong financial support (Worthington, 2004). The finding was in line with the need of achieving success in personal financial security. Likewise, if an individual has various types of financial products compared to only one product. Confidence in personal wealth will also be higher if individuals have a combination of various ownership of financial products, such as ordinary savings, emergency saving, equity deposits, insurance protection, unit trust and investment. The ownership here is intended not only to own without offsetting the proper 'value' for each product. For example, individuals have different types of savings accounts, but only at the minimum value for each. This is inadequate to achieve a better financial well-being.

Financial behavioral factors are also a key determinant of the probability level of the financial well-being of the workers in a dual-income family. Married workers in a dual-income family who practice good financial behaviours have the likelihood of achieving a relatively higher level of well-being. This is because the findings show that the probability of the financial behavior factor significantly affects the low-financial well-being and middle level financial wellbeing compared to the high-level financial well-being. The finding was similar to prior research (Kim et al., 2003; Joo \& Grable, 2004; Fazli, 2011; Zuroni \& Lin, 2012; Nur Aisyatul et al., 2015) which stated that good financial behavior would influence the level of financial wellbeing.

Additionally, positive financial behaviours can increase motivation in life. In the effort to meet the basic financial needs (expenditure), it should be accompanied by the need for savings, protection and investment. In this case, an employee with a basic financial knowledge will more easily achieve the goals of financial strength and well-being in life. However, this study is unable to prove that the relationship of financial knowledge with financial behaviour even though financial behaviour has a direct relationship and influence on the financial well-being of the married workers in dual-income families. This finding validates that having financial knowledge alone does not necessarily guarantee financial well-being without being accompanied by positive financial behaviour. In other words, knowledge without practice will not provide a good outcome.

In addition, the husband's financial decision-making factor also determines the probability of the financial well-being of the dual-income families of the workers in the public sector. Financial decision-making among the dual income families dominated by the husbands has the probability of being at a high level of financial well-being compared to the low-level financial well-being. This is due to a larger share of the income of a husband than his wife in the dualincome families in the public sector. Therefore, the husband still has more power or authority in making family financial decisions. This finding did not differ much from the previous family decision-making pattern (Bernasek \& Bajtelsmit, 2002; Siswati \& Puspawati, 2017). The expectation to see the financial decision making made together by the husband and wife to be 
more dominant in a dual-income family is not as evident in this study. This situation is also influenced by the culture of the society, especially those who are Muslims. Hence, the study concludes that socio-cultural factors strongly influence the retention of the financial decisionmaking pattern. This means that the factor of ownership or contribution of financial resources solely by spouses in a dual-income family cannot be a predictor of the change in the real-life decision-making pattern in a dual-income family.

\section{Conclusion and suggestions}

Study findings indicate that the level of financial well-being among married workers in dualincome family was at a moderate level. The three levels of financial well-being (low, moderate and high) among the respondents of the dual-income family were not solely being influenced by the increase in income. Instead, it was influenced by factors such as age, home ownership, financial product ownership, financial behavior and the decision making management by the husband.

The results of this study have several implications. Firstly, comprehensive effort should be carried out to focus on significant factors that influence the various levels of financial well-being of the respondents. The formulation of policy regarding workers, especially within the dualincome family itself ought to take into consideration of factors aforementioned. For example, workers in the youth group should be given exposure to positive practices of financial behavior in order to ensure their financial well-being. Efforts in encouraging home ownership among the workers need to be geared up and be given more serious attention. Focus should be given in terms of the power in loan repayment, since the cost of owning a home is increasing from time to time. The ownership of various financial products should be encouraged and not dependent on savings solely. They should have more insurance and investment to improve their level of financial well-being.

Secondly, the implication of the financial decision making by the husband was significant and it influenced the level of their financial well-being. A more effective and efficient approach in building family culture that promotes valuable financial decision making should be practiced among the female workers. Better handling of financial resources could assist people in overcoming the obstacles in life such as family break ups and death of marriage partners. Thirdly, even though the findings did not prove the correlation between financial knowledge with financial behavior among the respondents, focus should be given more on improving early education in financial security and well-being. In addition, financial education and healthy financial practices at the workplace should be encouraged, implemented and adapted as a good practice.

Finally, the adaptation of good values in life, such as applying simplicity in life is very important. Nowadays, most people fail in managing personal and family finances because of their behavior in spending more than they earn. The concept of simplicity in life is highly required in a Muslim world. Many experts in personal finance have encouraged and promoted the concept of simplicity in life and advised people to spend less than what they earn. This is in order to maintain strong financial standing as well as having increased level of financial wellbeing. In other words, the key word to ensuring the strength of one's financial well-being is to practice spending less than the income that they earn. 


\section{Acknowledgement}

Appreciation to Universiti Kebangsaan Malaysia in funding this research (UKM-SK-21-2007) and also grateful to the Faculty of Social Science and Humanities (DPP-2015-FSSK) for supporting this publication.

\section{References}

Baek, E., \& DeVaney, S.A. (2004). Assessing the baby boomers' financial wellness using financial ratios and a subjective measure. Family and Consumer Sciences Research Journal, 32, 421-348.

Bank Negara Malaysia. (2010). Annual Report 2009. Kuala Lumpur, Malaysia Government Printing Office.

Bank Negara Malaysia. (2013). Financial stability and payment systems report 2014. Kuala Lumpur, Malaysia Government Printing Office.

Bank Negara Malaysia. (2018). Financial stability and payment systems report 2017. Kuala Lumpur, Malaysia Government Printing Office.

Bernasek, A., \& Bajtelsmit, V.L. (2002). Predictors of women's involvement in household financial decision-making. Association for Financial Counseling and Planning Education. 13(2), 39-47.

Cox, A., Hooker, H., Markwick, C., \& Reilly, P. (2009). Financial well-being in the workplace. Report 464. Institute for Employment Studies. Retrieved from http://www.Employmentstudies.co.uk

Diana-Rose, F., \& Zariyawati, M.A. (2015). Factors affecting youth bankruptcy in Malaysia. UPM-SAGE Publications Young Writer's award 2015 Papers, Perpustakaan Sultan Abdul Samad, Universiti Putra Malaysia.

Economic Planning Unit. (2006). $9^{\text {th }}$ Malaysian Planning 2006-2010. Kuala Lumpur, Prime Minister Department of Malaysia. Retrieved from https://www.pmo.gov.my

Economic Planning Unit. (2010). 10th Malaysian Planning 2011-2015. Kuala Lumpur, Prime Minister Department of Malaysia. Retrieved from https://www.pmo.gov.my

Faoziah Idris, K. Sarojani Devi Krishnan, \& Norfiza Azmi. (2013). Relationship between financial literacy and financial distress among youths in Malaysia: An empirical study. Geografia-Malaysian Journal of Society and Space, 9(4), 106-117.

Fazli, M.S. (2011). Pathways to financial success: Determinants of financial literacy and financial well-being among young adults. Retrieved from https://www.researchgate.net/

Garman, E.T., \& Forgue, R.E. (2006). Personal Finance. $8^{\text {th }}$ edition. New York: Houghton Mifflin Company.

Goldsmith, E.B. (2005). Resource management for individuals and families. ( $3^{\text {rd }}$ ed.). United States, Thompson Wadsworth.

Haron, S.A., Sharpe, D.L., Masud, J., \& Abdul-Ghaney, M. (2010). Health divide: Economic and demographic factors associated with self-reported health among older Malaysians. Journal of Family Economic Issues, 31, 328-337.

Hasni, H. (2014). Factors that influence saving habits among Gen Y: Case study on students of Politeknik Sultan Azlan Shah (PhD dissertation). Retrived from, Universiti Utara Malaysia. 
Husniyah A.R., Syuhaily, O., Fazli, S.M. Amim, O., \& Ahmad Hariza, H. (2005). Gelagat perancangan kewangan keluarga di Malaysia. Malaysian Journal of Consumer and Family Economics, 8, 27-39.

Husniyah Abdul Rahim \& M. Fazilah Abdul Samad. (2009). The impact of financial management practices on financial well-being of families in Malaysia. Jurnal Pengguna Malaysia, 12, 27-41.

Jariah Masud. (2007). Testing of Malaysia's Financial Well-Being Scale. Seventh Biennial Conference 2007 ACFEA, Putrajaya, Malaysia. 4-7 July.

Joo, S., \& Grable, J.E. (2004). An exploratory framework of the determinants of financial satisfaction. Journal of Family and Issues, 25(1), 25-50.

Joo, S., \& Garman, E.T. (1998). Personal financial wellness maybe the missing factor in understanding and reducing worker absenteeism. Personal Finance and Worker Productivity, 2(2), 172-182.

Kapoor, J.R., Dlabay, L.D., \& Hughes, R.J. (2004). Personal finance. New York, McGraw-Hill.

Kim, J., \& Garman, E.T. (2004). Financial stress, pay satisfaction and workplace performance. Financial Education, 69-76.

Kim, J., Garman, E.T., \& Sorhaindo, B. (2003). Relationships among credit counseling clients' financial well-being, financial behaviors, financial stressor events, and health. Financial Counseling and Planning Education, 14(2), 75-87.

Kim, J., Sorhaindo, B., \& Garman, E.T. (2004). Financial stress and work outcomes of credit counseling clients. Consumer Interest Annual, 50, 128-130.

Lown, J.M., \& Ju, I. (2003). A model of credit use and financial satisfaction. Financial Counseling and Planning, 3, 105-123.

Malaysian Insolvency Department. (2010). Bankruptcy Statistic December 2009. Retrieved from www.mdi.gov.my

Mokhtar, N., \& Husniyah, A.R. (2017). Determinants of financial well-being among public employees in Putrajaya, Malaysia. Pertanika Journal Social Science \& Humanities, 25(3), 1241-1260.

Noorhaslinda Kulub Abd. Rashid, Aslina Nasir, Zuraini Anang, Roseliza Mat Alipiah, Rahmah Ismail, Sanep Ahmad \& S. Shahida. (2018). Determinants of Muslim household basic needs consumption expenditures. Jurnal Ekonomi Malaysia, 52(1), 283 - 295

Nur Aisyatul Radiah Alidaniah, Sanep Ahmad, Mohd Ali Mohd Noor \& Mohammed Riski Moi. (2015). Gelagat hutang isi rumah mengikut kaum di Bandar Baru Bangi, Selangor. Malaysian Journal of Society and Space, 11(11), 110-119.

Nuraini Abdullah \& Sabri, M.S. (2016). Faktor peramal pengurusan hutang dalam kalangan pekerja muda. International Journal of Education and Training, 2(2), 1-19.

Nurul Shahnaz, Ahmad Mahdzan \& M. Fazilah Abdul Samad. (2005). Financial management practices of married couples in urban Malaysia. Malaysian Journal of Consumer and Family Economics, 8, 40-50.

O'neill, B, Xiao, J.J., Sorhaindo, B., \& Garman, E.T. (2005). Financially distressed consumers: Their financial practices, financial well-being, and health. Financial Counseling and Planning, 16(1), 73-87.

Poh, L.M., \& Sabri, M.F. (2017). Review of financial vulnerability studies. Archives of Business Research, 5(2), 127-134.

Porter, N.M., \& Garman, E.T. (1993). Testing a conceptual model of financial well-being. Financial Counseling. and Planning, 4, 135-164. 
Prawitz, A.D., Garman, E.T., Sohaindo, B., \& Drentea, P. (2006). InCharge Financial Distress/Financial Well-Being Scale: Development, administration, and score interpretation. Retrieved from https://pfeef.org

Rutherford, L.G., \& Fox, W.S. (2010). Financial wellness of young adults age 18-30. Family \& Consumer Sciences Research Journal, 38(4), 468-484.

Shim, S., Xiao, J.J., Barber, B.L., \& Lyons, A.C. (2009). Pathway to life success: A conceptual model of financial well-being for young adults. Journal of Applied Development Psychology, 30(6), 708-723.

Siswati, M.K., \& Puspiwati, H. (2017). Peran gender, pengambilan keputusan, dan kesejahteraan keluarga dual-earner. Jurnal Ilmu Keluarga dan Konsumen, 10(3), 169-180. https://doi.org/10.24156/jikk.2017.10.3.169

Toh Siaw Mien, \& Rusmawati Said. 2018. A cross-sectional household analysis of household consumption patterns: An indirect approach to identify the possible factors of personal bankruptcy. Jurnal Ekonomi Malaysia, 52(3), 231-246.

Worthington, A.C. (2004). Adequacy and determinants of emergency funds in Australian households. Financial Counseling and Planning, 15(1), 21-30.

Xiao, J.J., Sorhaindo, B., \& Garman, E.T. (2004). Financial behaviors of consumers in credit counseling. Consumer Interest Annual, 50, 131-133.

Zaimah, R., Sarmila, M.S., Selvadurai, S., Lyndon, N., Er, A.C., \& Jamain, M.N. (2013). The history and current status of dual-career families in Malaysia. Asian Social Sciences, 9(6), 16-21.

Zuroni, M.J., \& Lin, L.Y. (2012). Personal financial knowledge and attitude towards credit card practices among working adults in Malaysia. International Journal of Business and Social Science, 3, 176-185. 